\title{
Rhodamine 6G and Au-Pd core-shell nanorods: fluorescence enhancement for detection of mercury
}

${ }^{1}$ Ekkachai Rammarat, ${ }^{2}$ Sasiwimon Kraithong, ${ }^{3}$ Nantanit Wanichacheva,

${ }^{4}$ Pattanawit Swanglap, ${ }^{5}$ Witoon Yindeesuk, ${ }^{6}$ Pattareeya Damrongsak and

${ }^{7}$ Kitsakorn Locharoenrat

${ }^{1}$ Department of Physics, Faculty of Science, King Mongkut's Institute of Technology Ladkrabang, Bangkok 10520 Thailand; 58605017@kmitl.ac.th

${ }^{2}$ Department of Chemistry, Faculty of Science, Chulalongkorn University, Bangkok 10330 Thailand; sasi_m4@hotmail.com

${ }^{3}$ Department of Chemistry, Faculty of Science, Silpakorn University, Nakornpathom 73000 Thailand; wanichacheva.nantanit@gmail.com

${ }^{4}$ Department of Chemistry, Faculty of Science, Silpakorn University, Nakornpathom 73000 Thailand; swanglap_p@su.ac.th

${ }^{5}$ Department of Physics, Faculty of Science, King Mongkut's Institute of Technology Ladkrabang, Bangkok 10520 Thailand; witoon.yi@kmitl.ac.th

${ }^{6}$ Biomedical Physics Research Unit, Department of Physics, Faculty of Science, King Mongkut's Institute of Technology Ladkrabang, Bangkok 10520 Thailand; pattareeya.da@kmitl.ac.th

${ }^{7}$ Biomedical Physics Research Unit, Department of Physics, Faculty of Science, King Mongkut's Institute of Technology Ladkrabang, Bangkok 10520 Thailand; kitsakorn.lo@kmitl.ac.th

Received: 13.09 .2018

Abstract. We show that hybrid organic-inorganic particles are efficient for accurate sensing of mercury ions and following up trace amounts of the mercury pollutions spread in the environment. The process of synthesis of a working substance starts from preparation of rhodamine $6 \mathrm{G}$ derivative. Then the dye molecules are bound on the surface of $\mathrm{Au}-\mathrm{Pd}$ core-shell nanorods. Mercury ions with different concentrations are finally attached onto this fluorescence sensor. Fluorescence emission of the sensor is detected with a luminescence spectrophotometer. The experimental results demonstrate that the fluorescence intensity of one of our sensors, a sensor B, is remarkably enhanced when the mercury-ion concentration increases from 0 to $15.5 \mu \mathrm{M}$. The limit of detection of the ions is as low as $20.6 \mathrm{nM}$. The working mechanism of our fluorescence sensor can be explained through the fluorescence-energy transfer and the plasmonic effect associated with spirolactam forms of rhodamine and conducting bimetallic nanoparticles.

Keywords: dyes, nanoparticles, mercury, detection limit

PACS: $33.50 . \mathrm{Dq}$, 78.67.Qa

UDC: 535.371

\section{Introduction}

Mercury is a harmful heavy metal which represents a dangerous global pollutant [1]. Since mercury is widely spread in air, water and soil, it can approach human bodies both dermally and orally. Moreover, many bacteria are able to convert inorganic mercury into methyl mercury in the environment [2]. Mercury tends to combine with thiol groups in biological systems, e.g. enzymes, thus causing severe problems in human bodies [3, 4]. Finally, mercury in its vapour form is 
allergic to human immunity, digestion, skin, kidneys, lungs, and nervous systems [3]. Therefore, it causes many serious diseases, such as nephritic syndrome, Minamata disease, cyanosis, pulmonary edema and intelligence quotient loss [5].

Since mercury contamination is a ubiquitous global problem, there is a huge need in sensitive and selective techniques for its detection [6]. Up to date, a number of appropriate tools there have been developed, some of which prove to be highly sensitive in mercury detection. Mass spectrometry, atomic absorption spectrometry, atomic fluorescence spectrometry [7] and gas chromatography [8] belong to these tools. However, they are often expensive, complicated and time consuming. These factors restrict their utilization in onsite tests $[6,8,9]$. So far, the fluorescence approaches are also considered as good devices for tracking the trace amounts of the above metal ions due to their low cost and quick response times suitable for the real-time observations $[8,10,11]$. Nonetheless, the sensitivities of many fluorophores are not sufficient enough [12-14]. Among fluorophores developed recently, rhodamine is interesting because of its promising fluorescence properties [15], high fluorescence quantum yield [11], low cost [16], convenient fluorescence emission, and absorption spectra centred in the visible range [8]. Note that spirolactam-type rhodamine derivatives are non-fluorescent while spirolactam ring openings stipulate increasing fluorescence intensity [17]. It is also important that such a fluorescence sensing system can be improved via metal-enhanced fluorescence phenomena.

Although there are many combinations of monometallic nanoparticles and organic dyes that reveal high sensitivity in detecting mercury ions (see Table 1), no studies have been reported on bimetallic nanoparticles with organic dyes as fluorescence enhancers. In the present work, we suggest using of rhodamine $6 \mathrm{G}(\mathrm{R} 6 \mathrm{G})$ hydrazine derivative and $\mathrm{Au}-\mathrm{Pd}$ core-shell nanorods (abbreviated as Au@Pd) in a fluorescence sensor. This sensor has been built and its sensitivity and selectivity of detection of the mercury ions $\mathrm{Hg}$ (II) has been checked in a particular case when the $\mathrm{Hg}$ (II) concentrations are varied from 0 to $15.5 \mu \mathrm{M}$. It has turned out that the limit of detection of $\mathrm{Hg}$ (II) can be drastically improved when the concentration ratio of R6G and Au@Pd is chosen properly. Although our experimental data are not so amazing as those reported in Refs. [18-21], the detection limits in this study are lowered down to $\mathrm{nM}$ levels. In other words, we offer a ponderable alternative to the present-day techniques for instantaneous determination of $\mathrm{Hg}(\mathrm{II})$ contents, which is very simple and needs neither cumbersome sample preparation nor complicated instrumentation. Moreover, our method can become a starting point in development of compact portable instruments for onsite $\mathrm{Hg}(\mathrm{II})$ detection.

Table 1. Monometallic nanoparticles and organic dyes reported in the literature for sensing mercury ions.

\begin{tabular}{ccccc}
\hline Sensor & \multicolumn{4}{c}{ Limit of detection of Hg(II) } \\
\hline \multicolumn{1}{c}{ References } & $\begin{array}{c}\text { Brasca et al. } \\
{[18]}\end{array}$ & $\begin{array}{c}\text { Wang et al. } \\
{[19]}\end{array}$ & $\begin{array}{c}\text { Hsin-Yun et al. } \\
{[20]}\end{array}$ & $\begin{array}{c}\text { Josiane et al. } \\
{[21]}\end{array}$ \\
\hline $\mathrm{Au}+$ Rhodamine 6G & $0.75 \mathrm{nM}$ & - & $10.0 \mathrm{nM}$ & $7.0 \mathrm{nM}$ \\
$\mathrm{Ag}+$ Victoria blue B & - & $0.20 \mathrm{nM}$ & - & - \\
\hline
\end{tabular}

\section{Materials and methods}

$100 \mathrm{mg}$ of rhodamine 6G (R6G from Sigma Aldrich, USA) and $0.1 \mathrm{~mL}$ triethyamine were dissolved in $5 \mathrm{~mL}$ of absolute ethanol in argon atmosphere for $30 \mathrm{~min}$. Then $0.1 \mathrm{~mL}$ of hydrazine monohydrate was added to the solution. This mixture solution was heated for $24 \mathrm{~h}$ in the argon 
atmosphere to reflux. After natural cooling, a residue was filtered and dried at ambient temperature. A solid R6G-hydrazine derivative $(67 \mathrm{mg})$ was finally obtained.

Au@Pd nanorods were bought from Nanoseedz (Hong Kong). They had the diameter $40 \pm 3 \mathrm{~nm}$ and the length $96 \pm 6 \mathrm{~nm}$. The concentrations of constituents of a mixture of R6Ghydrazine and Au@Pd, which have been prepared when designing our sensors, are displayed in Table 2.

Table 2. Concentrations of constituents prepared for designing our four sensors referred to as A, B, $\mathrm{C}$ and $\mathrm{D}$ further on. Note that the $\mathrm{M}$ unit is mole/L.

\begin{tabular}{lll}
\hline Sensor & R6G $(\mu \mathbf{M})$ & Au@Pd $(\mathbf{M})$ \\
\hline A & 4.4 & - \\
B & 4.4 & $10^{-5}$ \\
C & 4.4 & $10^{-6}$ \\
D & 4.4 & $10^{-7}$ \\
\hline
\end{tabular}

In order to test the surfaces for metal sorption, different types of metal ions $(\mathrm{Na}(\mathrm{I}), \mathrm{K}(\mathrm{I})$, $\mathrm{Ag}(\mathrm{I}), \mathrm{Cu}(\mathrm{II}), \mathrm{Pb}$ (II), $\mathrm{Ca}(\mathrm{II}), \mathrm{Hg}$ (II) and $\mathrm{Fe}(\mathrm{III})$ obtained from Sigma Aldrich, USA) were used. Their concentrations varied in the region $0-15.5 \mu \mathrm{M}$. The emission intensity for each of the sensors was recorded with a luminescence spectrophotometer (Perkin Elmer LS-50B). The excitation and emission wavelengths were 500 and $550 \mathrm{~nm}$, respectively. All the experimental measurements were repeated three times at the room temperature.

\section{Results and discussion}

Fig. 1 displays the fluorescence spectra detected with four different sensors produced according to Table 2. Here a sensor B reveals a maximal peak due to the following reasons. A transfer of the fluorescence energy from rhodamine molecules to Au@Pd causes damping of dipole oscillations by a nearby metal, whereas the conducting metallic nanoparticles increase the local incident field at the rhodamine molecules. The latter fact is understood as a plasmonic effect, which increases subsequently the excitation rate. Furthermore, a nearby metal increases the intrinsic radiative decay rate for the rhodamine molecules and so increases the emission rate. These effects play an important role in further enhancement of the fluorescence intensity for the sensor B. As a consequence, the sensor B has been selected as a suitable representative for detecting different metal ions.

Fig. 2 shows the fluorescence spectra for the sensor B in case if its working substances are mixed with different types of metal ions. Here $\mathrm{Na}$ (I), $\mathrm{K}$ (I), $\mathrm{Ag}(\mathrm{I}), \mathrm{Cu}(\mathrm{II}), \mathrm{Pb}(\mathrm{II}), \mathrm{Ca}$ (II), $\mathrm{Hg}$ (II) and

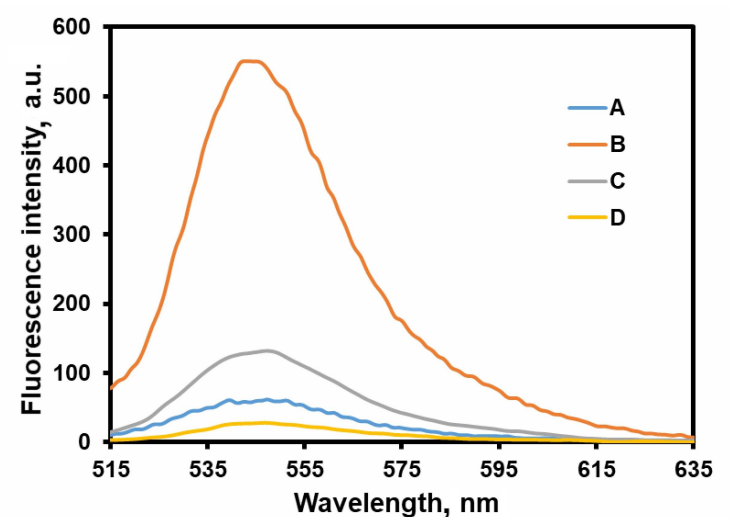

Fig. 1. Fluorescence spectra detected with our sensors of different types (see Table 2). 
Fe(III) are used as representatives of metal ions in the tap water. Note that the concentrations of each of the metal ions have been kept at the level of $15.5 \mu \mathrm{M}$. We have found that the sensor B represents a good sensing system, owing to its high selectivity with respect to analyte $\mathrm{Hg}(\mathrm{II})$.

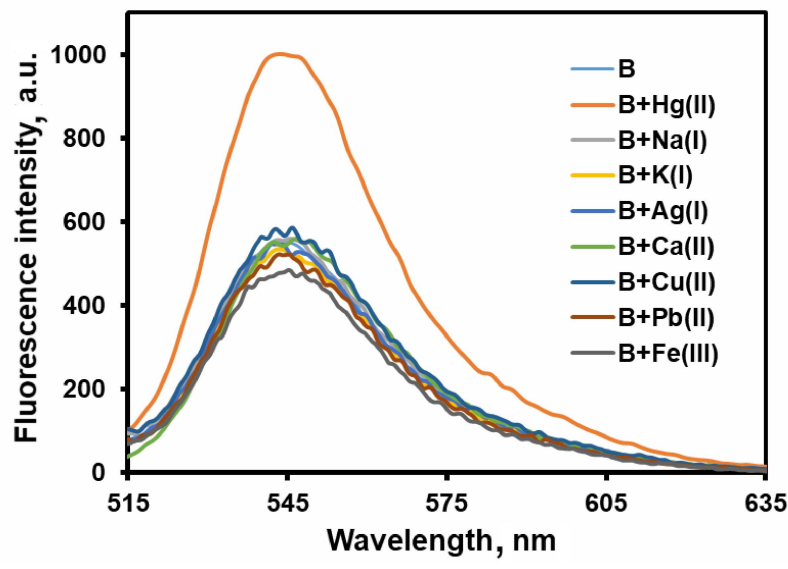

Fig. 2. Fluorescence spectra detected with the sensor $B$ in the case of different types of metal ions (see the legend). Concentrations of all the metals are the same $(15.5 \mu \mathrm{M})$.

Fig. 3 demonstrates that, in a particular case when we deal with $10.0 \mu \mathrm{M}$ of $\operatorname{Hg}(\mathrm{II})$, the sensitivity of the sensor B is notably higher than that of the sensor A. At least two factors can contribute to its high selectivity with respect to $\mathrm{Hg}(\mathrm{II})$. First, the fluorescence energy transfer and the plasmonic effect between R6G and Au@Pd occur when the spirolactam-amide ring opening in R6G-hydrazine is bound with the Au@Pd surface. Second, these two components act as donors for $\mathrm{Hg}(\mathrm{II})$ probe at the surface, thus inducing a drastic increase in the fluorophoric radiative rate [17].

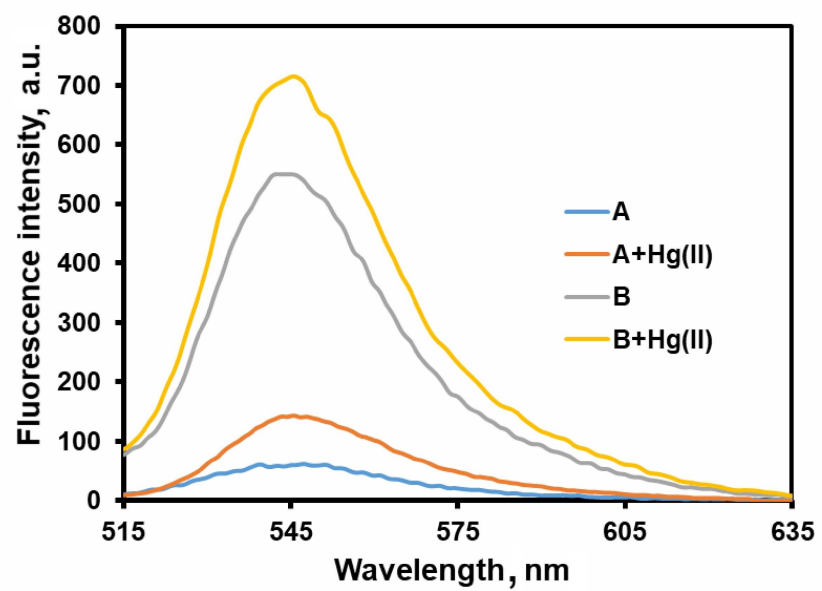

Fig. 3. Fluorescence spectra for the sensors A and B detected for the $\mathrm{Hg}(\mathrm{II})$ concentration $10.0 \mu \mathrm{M}$.

Now we focus on the sensitivity of $\mathrm{Hg}(\mathrm{II})$ chelating agent by the sensor B. Fig. 4 shows the fluorescence spectra detected with the sensor B for seven different $\mathrm{Hg}(\mathrm{II})$ concentrations, which are equal to $0,7.5,10.0,11.5,13.0,14.5$ and $15.5 \mu \mathrm{M}$. Here the fluorescence intensity depends heavily on the concentration. A gradual increase in the $\mathrm{Hg}$ concentration leads to increasing emission at approximately $550 \mathrm{~nm}$. The sensor B turns out to be a good candidate for reliable detection of $\mathrm{Hg}(\mathrm{II})$. 


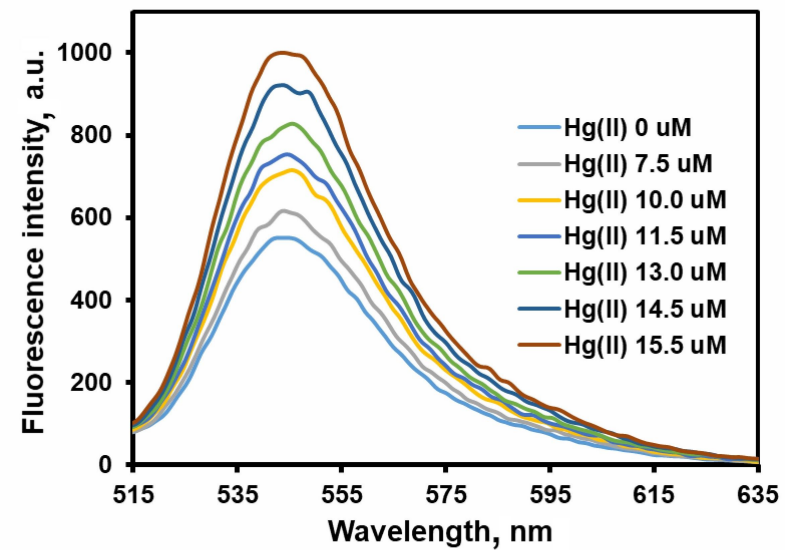

Fig. 4. Fluorescence spectra detected with the sensor B for different $\mathrm{Hg}(\mathrm{II})$ concentrations (shown in the legend).

Dependence of the peak fluorescence intensity on the metal concentration is displayed in Fig. 5. A nonlinear optical response $y$ can be fitted with the relation $y=2.4372 x^{2}-9.2612 x-550.72$, where $x$ stands for the concentration. Since the sensor works at the ion concentrations close to zero, the quadratic term can be neglected. Hence, the fit can be rewritten as $y \cong-9.2612 x-550.72$. Then the detection limit LOD can be estimated as in Ref. [22]:

$$
L O D=\frac{k}{a} \sqrt{\frac{S D^{2}}{n}+\frac{R_{i r}^{2}}{12}},
$$

where the parameters entering Eq. (1) are specified and explained in Table 3.

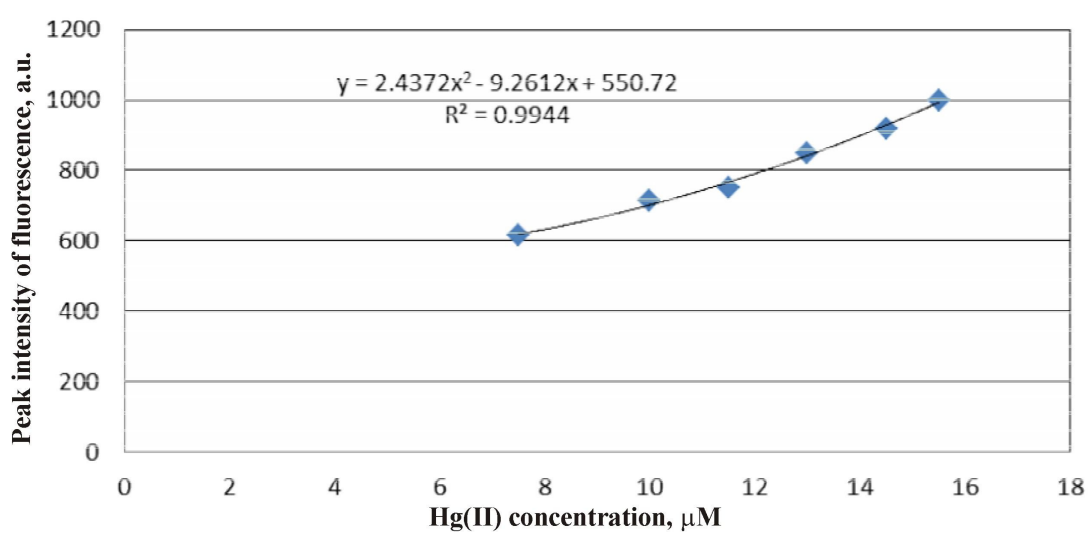

Fig. 5. Dependence of peak fluorescence intensity detected by the sensor $\mathrm{B}$ on the $\mathrm{Hg}(\mathrm{II})$ concentration.

Table 3. Parameters used in our calculation of the detection limit $L O D$ (see Eq. (1)).

\begin{tabular}{lcc}
\hline Parameter & Symbol & Value \\
\hline Uncertainty constant (see Ref. [22]) & $k$ & 3 \\
Slope of the linear fit & $a$ & 9.2612 a.u./ $\mu \mathrm{M}$ \\
Standard deviation & $S D$ & 0.11 a.u. \\
$\begin{array}{l}\text { Cycle of fluorescence intensity } \\
\text { measurements at each metal concentration }\end{array}$ & $n$ & 3 \\
Readout instrument resolution & $R_{i r}$ & 0.01 a.u. \\
\hline
\end{tabular}

Ukr. J. Phys. Opt. 2018, Volume 19, Issue 4 
Substituting the parameters of Table 3 into Eq. (1), we obtain the detection limit $20.6 \mathrm{nM}$ for our sensor B. Of course, the limit of detection of bimetallic nanoparticles with our fluorescence sensor based on the organic dye is somewhat higher than those typical for the sensors associated with monometallic nanoparticles and organic dyes, for which the loading content is close to $0.2-$ $10.0 \mathrm{nM}$ [18-21]. On the other hand, the mercury concentration level corresponding to our detection limit for the sensor B is less than the harmless level set by the Environmental Protection Agency for the tap water (Fact Sheet EPA-823-F-01-011, USA) [23]. This testifies viability and practical importance of the simple technique suggested in the present work.

\section{Conclusion}

We prove that the surface of rhodamine 6G modified by Au@Pd enhances notably the fluorescence intensity. The fluorescence sensor referred to as the 'sensor B' is found to be particularly selective to the mercury ions, if compared with the other metal ions. Since increasing concentration of these ions enhances significantly the fluorescence intensity of the sensor, this sensor can detect the amount of the mercury ions. Issuing from the experimental response of the fluorescence to the mercury-ion concentration, we have found that the detection limit is equivalent to $20.6 \mathrm{nM}$. Although our detection limit for mercury is somewhat worse than those reported in the previous studies, the corresponding amount of mercury ions is well below the limits recommended for the tap water and set by the Environmental Protection Agency.

The increase in the fluorescence emission observed by us in comparison with the closest sensor analogues can be attributed to increased incident electric field felt by the rhodamine molecules under the conditions of close proximity to the metal nanoparticles. We expect that, due to its simplicity and high selectivity and sensitivity, the fluorescence sensor developed in this study can be employed as a good mercury-ion detector for many industrial applications.

\section{Acknowledgement}

This research is funded by the King Mongkut's Institute of Technology Ladkrabang (Bangkok, Thailand).

\section{References}

1. Miao-Miao H, Ai-Feng L, Ying X and Dong-Mei X, 2016. Synthesis and properties of three novel rhodamine-based fluorescence sensors for $\mathrm{Hg}^{2+}$. Chin. Chem. Lett. 27: 989-992.

2. Kai-Hui C, Yi Z, Yuan F, Li-Hong W, Ju-Ying L and Cheng Y, 2013. Rhodamine-pyrene conjugated chemosensors for ratiometric detection of $\mathrm{Hg}^{2+}$ ions: Different sensing behavior between a spirolactone and a spirothiolactone. Dyes and Pigments. 98: 339-346.

3. Zohreh P, 2018. Electrospun nanofibers decorated with bio-sonochemically synthesized gold nanoparticles as an ultrasensitive probe in amalgam-based mercury (II) detection system. Ultrasonics-Sonochemistry. 44: 24-35.

4. Jingkai N, Bin L, Liming Z, Haifeng $\mathrm{Z}$ and Hong J, 2015. A fluorescence turn-on probe based on rhodamine derivative and itsfunctionalized silica material for $\mathrm{Hg}^{2+}$-selective detection. Sensors and Actuators B. 215: 174-180.

5. Pandeeswar M, Rohilla S, Ahmad E K, Selvakannan R P, Ylias M S, Chilakapati M, Suresh K B and Thimmaiah G. 2018. SERS and fluorescence-based ultrasensitive detection of mercury in water. Biosensors and Bioelectronics. 100: 556-564.

6. Jingkai N, Qiuyan L, Bin L and Liming Z, 2013. A novel fluorescence probe based on rhodamine B derivative for highly selective and sensitive detection of mercury(II) ion in 
aqueous solution. Sensors and Actuators B. 186: 278-285.

7. Yonglei C, Shuyun H, Shenghong Y and Qiaosheng P, 2017. Rhodanine stabilized gold nanoparticles for sensitive and selective detection of mercury (II). Dyes and Pigments. 142: 126-131.

8. Xuan Z and Ying-Ying Z, 2014. A new fluorescence chemodosimeter for $\mathrm{Hg}^{2+}$-selective detection in aqueous solution based on $\mathrm{Hg}^{2+}$-promoted hydrolysis of rhodamine-glyoxylic acid conjugate. Sensors and Actuators B. 202: 609-614.

9. Fanyong Y, Meng W, Donglei C, Ning Y, Yang F, Li C and Ligong C, 2013. New fluorescence and colorimetric chemosensors based on the rhodamine detection of $\mathrm{Hg}^{2+}$ and $\mathrm{Al}^{3+}$ and application of imaging in living cells. Dyes and Pigments. 98: 52-50.

10. Lijuan F, Jie S, Yao H, Shaopeng C, Bingxin L, Haixia Z and Changli L, 2015. Conjugated polymer and spirolactam rhodamine-B derivative co-functionalized mesoporous silica nanoparticles as the scaffold for the FRET-based ratiometric sensing of mercury (II) ions. Microporous and Mesoporous Mater. 208: 113-119.

11. Ajcharapan T, Samran P, Kanoknetr S and Palangpon K, 2018. A thiourea-appended rhodamine chemodosimeter for mercury(II) and its bioimaging application. Spectroch. Acta A: Molec. Biomolec. Spectrosc. 192: 101-107.

12. Nikolai I. Georgiev, Margarita D.Dimitrova, Abdullah M.Asirib, Khalid A.Alamry, Vladimir B.Bojinov, 2015. Synthesis, sensor activity and logic behavior of a novel bichromophoric system based on rhodamine 6G and 1,8-naphthalimide. Dyes and Pigments. 15: 172-180.

13. Kyeong S M, Ramalingam M and Young A S, 2018. Rhodamine-fluorene based dual channel probe for the detection of $\mathrm{Hg}^{2+}$ ions and its application in digital printing. Sensors and Actuators B. 261: 545-552.

14. Jiang-Hao H, Shuai H, Xiaoyan W, Min L and Haifei L, 2017. Au-Pt-Au nanoraspberry structures used for mercury ion detection. Opt. Eng. 56: 127104.

15. Xin Z, Wei Y, Tong Z, Zhexi T and Xue W, 2013. Rhodamine based derivative and its zinc complex: synthesis and recognition behavior toward $\mathrm{Hg}(\mathrm{II})$. Tetrahedron 69: 9535-9539.

16. He S, Liu Q, Li Y, Wei F, Cai S, Lu Y and Zeng X, 2014. Rhodamine 6G-based chemosensor for the visual detection of $\mathrm{Cu}^{2+}$ and fluorescence detection of $\mathrm{Hg}^{2+}$ in water. Chem. Res. in Chin. Univ. 30: 32-36.

17. Yanqing G, Xujiao X, Aikun L, Ruixue J, Shili S and Xiaoqun C, 2017. A novel imidazo[1,5-a] pyridine-rhodamine FRET system as an efficient ratiometric fluorescence probe for $\mathrm{Hg}^{2+}$ in living cells. Dyes and Pigments. 146: 136-142.

18. Brasca R, Onaindia M C, Goicoechea H C, Peña A M and Culzoni M J, 2016. Highly selective and ultrasensitive turn-on luminescence chemosensor for mercury (II) determination based on the rhodamine 6G derivative FC1 and Au nanoparticles. Sensors. 16: 1652.

19. Wang Y, Wen G, Ye L, Liang A and Jiang Z, 2016. Label-free SERS study of galvanic replacement reaction on silver nanorod surface and its application to detect trace mercury ion. Sci. Rep. 6: 19650.

20. Hsin-Yun C, Tung-Ming H, Yu-Fen H and Chih-Ching, H. 2011. Using rhodamine 6Gmodified gold nanoparticles to detect organic mercury species in highly saline solutions. Envir. Sci. \& Technol. 45: 1534-1539.

21. Josiane P L, Thomas G J and Jorg P K, Gold nanoparticle-based microfluidic sensor for mercury detection. $15^{\text {th }}$ Int. Conf. on Miniaturized Syst. for Chemistry and Life Sciences. Washington, USA, 2-6 October 2011; p. 1317. 
22. Lavín A, de Vicente J, Holgado M, Laguna M F, Casquel R, Santamaría B, Maigler M V, Hernández A L and Ramírez Y, 2018. On the determination of uncertainty and limit of detection in label-free biosensors. Sensors. 38: 2038

23. United States Environmental Protection Agency. Available online: https://www.scribd.com/document/21847260/United-States-Environmental-Protection-Agency (accessed on 25 July 2018).

Ekkachai Rammarat, Sasiwimon Kraithong, Nantanit Wanichacheva, Pattanawit Swanglap, Witoon Yindeesuk, Pattareeya Damrongsak and Kitsakorn Locharoenrat. 2018. Rhodamine 6G and $\mathrm{Au}-\mathrm{Pd}$ core-shell nanorods: fluorescence enhancement for detection of mercury. Ukr.J.Phys.Opt. 19: 191 - 198. doi: 10.3116/16091833/19/4/198/2018

Анотація. Показано, щзо гібридні органічно-неорганічні частинки ефективні для точного визначення іонів ртуті та подальшого відстеження забруднення ртуттю, яка поширена в навколишньому середовищі. Процес синтезу робочої речовини починається з одержання похідної родаміну 6G. Потім молекули барвника зв'язують на поверхні наностержнів АиPd типу ядро-оболонка. Надалі іони ртуті з різними концентраціями налипають на даний датчик флуоресцениії. Флуоресцентну емісію датчика реєструють люмінесцентним спектрофотометром. Експериментальні результати показують, щчо інтенсивність флуоресиениії одного з наших датчиків - датчика $B$ - помітно посилюється, якщо концентрація ртутних іонів зростає від 0 до 15,5 мкМ. Межа чутливості виявлення изих іонів досягає 20,6 нм. Робочий механізм датчика флуоресцениї пояснюється передаванням флуоресцентної енергії та плазмонним ефектом, пов'язаним зі спіролактамними формами родаміну та провідними біметалічними наночастинками. 